\title{
Mosaic structure of the fungal community in the Kislo-Sladkoe Lake that is detaching from the White Sea
}

\author{
Olga A. Grum-Grzhimaylo ${ }^{1}$ (D) Alfons J. M. Debets ${ }^{2}$ - Elena N. Bilanenko ${ }^{3}$
}

Received: 13 November 2017 / Revised: 1 April 2018 / Accepted: 1 June 2018 / Published online: 16 June 2018

(c) The Author(s) 2018

\begin{abstract}
The major part of the north polar region is intensely rising by postglacial crustal movement. This process gives rise to the separation of different basins from seas and oceans, which affects a combination of freshwater and marine organisms. Gradually losing contact with the seas, many near-shore lakes of the Arctic are mostly desalted and form bogs. Fungi as decomposers play an important role in all ecosystems. However, the diversity and role of fungi in Arctic aquatic ecosystems is largely unknown. It is also not clear how the taxonomic structure of the fungal community is affected by the process of gradual desalinization and waterlogging. We investigated the diversity of filamentous culturable fungi in different parts of the brackish Kislo-Sladkoe Lake (White Sea, Russia). Annually, 42 samples of the bottom and coastal soils have been collected at the lake from which fungi were recovered on standard and selective media. Based on morphological and molecular markers, a total of 127 taxa have been identified. The fungal community appeared to be influenced by its sea origin and comprised both marine (Paradendryphiella salina, Acremonium spp.) and terrestrial soil species of Penicillium, Talaromyces, Mucor, Umbelopsis, Cladosporium, Cadophora, Sistotrema, Helotiales, Pleosporales, sphagnum moss destructors (Oidiodendron spp.) and insect-associated species of Tolypocladium. The results indicate that the composition of the fungal community in the rising polar White Sea region reflects the dynamics of global changes in physical-chemical parameters and animal and plant associations because of separation from the sea.
\end{abstract}

Keywords Fungal diversity $\cdot$ Brackish lake $\cdot$ Glacioisostatic movement $\cdot$ Coastal rising

\section{Introduction}

Some Arctic oceanic and marine coastal zones are intensely rising because of glacio-isostatic movement (Krasnova et al. 2013). As a result, water bodies are detaching from seas and

Electronic supplementary material The online version of this article (https://doi.org/10.1007/s00300-018-2347-9) contains supplementary material, which is available to authorized users.

Olga A. Grum-Grzhimaylo

olgrgr@wsbs-msu.ru

1 White Sea Biological Station, Faculty of Biology, Lomonosov Moscow State University, 1-12 Leninskie Gory, 119234 Moscow, Russia

2 Laboratory of Genetics, Plant Sciences Group, Wageningen University, Droevendaalsesteeg 1, 6708PB Wageningen, The Netherlands

3 Department of Mycology and Phycology, Faculty of Biology, Lomonosov Moscow State University, 1-12 Leninskie Gory, 119234 Moscow, Russia oceans and transforming to meromictic lakes in northern parts of North America and Eurasia (Fig. 1; Dickman 1978; Ludlam 1996; Gibson et al. 2002; Hakala 2004; Lutz and Kaulfuß 2006; Van Hove et al. 2006; Pouliot et al. 2009; Strelkov et al. 2014; Gulati et al. 2017). The coastal line of the White Sea (Russia) is a prominent example of this natural phenomenon. The shoreline of the western part of the White Sea is flat and indented; hence, the consequence of the coastal rising is the separation of the water bodies such as bays, armlets, and small lakes from coastal straits. These lakes gradually lose their connection with the sea and transform into different types of coastal basins varying in depth. Lakes with a depth of more than $6 \mathrm{~m}$ transform into meromictic lakes, while those with a depth of $1-6 \mathrm{~m}$ b transform into boggy fresh lakes. If the depth is less than $1 \mathrm{~m}$, the lakes form marshes (Pantiulin and Krasnonva 2011).

The lakes that are separating from the White Sea combine both marine and continental features and represent a unique environmental niche. These basins are still connected to the sea in a varying degree, while also having inflow of 


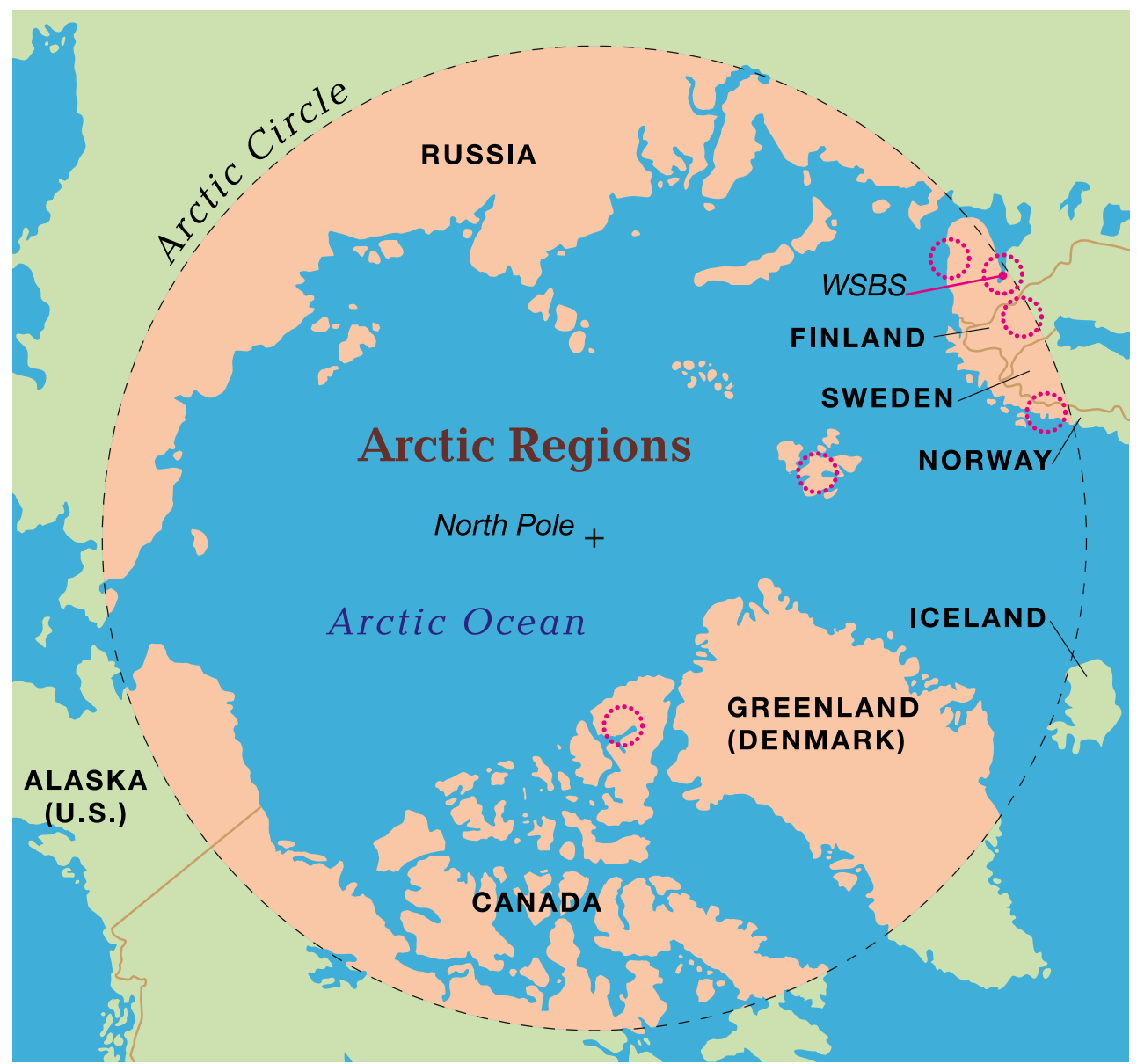

Fig. 1 The studied meromictic lakes in the Arctic region are marked by the circles; WSBS the White Sea biological station

fresh water from inland. Therefore, the main feature of these lakes is a strong vertical stratification governed by dynamics of fresh and salt water influx (Vinogradov et al. 2015). As a result, such detaching lakes harbour unique biota comprising a combination of freshwater and marine organisms (Krasnova et al. 2013). The shore-lines of these lakes are equally interesting biotopes. Horizontal nearshore currents distribute inflowing marine and fresh water along the shores. Therefore, coastal soil and littoral ground are composed of different zones with fluctuating environmental conditions, such as humidity, salinity and $\mathrm{pH}$ values. The mosaic coastal vegetation of these lakes highlights the soil patchiness (Sidneva 2008). Consequently, these transitional ecosystems represent extreme habitats and good systems for studying the general regularities in the formation of anaerobic conditions. These water bodies also represent unique objects for investigations of the biogeochemical processes that take place in water and sediments, and the interaction of freshwater and marine organisms. Scientists from various disciplines have explored the hydrology, flora and fauna of the water bodies at different stages of isolation from the White Sea (Krasnova et al. 2013). However, the fungal diversity and the role of fungi in meromictic and brackish lakes are poorly studied, although some data are available on fungi from meromictic lakes of Canada, Japan, France and Germany (Takishitaa et al. 2007; McAndrews and Turton 2010; Oikonomou et al. 2015; Lepère et al. 2016). So far, there have been no studies on the fungal biodiversity in separating lakes in Russia. Yet, littoral zone and marine bottom sediments including polar marine waters are specific ecotopes for fungi, with respect to biodegradation, symbiotic relationships and other functions (Damare et al. 2006; Damare and Raghukumar 2008; Bubnova 2017; Furbino et al. 2017; Rämä et al. 2017).

In this study, we further explore the fungal biodiversity in the Kislo-Sladkoe Lake, which is detaching from Kandalaksha Bay of the White Sea. This lake is a wellinvestigated site as a model of separating water reservoirs located in this region. It is located near the Pertsov White Sea Biological Station (WSBS; $66^{\circ} 34^{\prime} \mathrm{N}, 33^{\circ} 08^{\prime} \mathrm{E}$; Online Resource 1) of the Lomonosov Moscow State University and is at an initial stage of peatland formation because of its shallow waters $(4.5 \mathrm{~m}$ maximum depth). Over recent 
years, the Kislo-Sladkoe Lake has been examined with a wide range of approaches (Sidneva 2008; Krasnova et al. 2013, 2014, 2015; Malyshko et al. 2015; Vinogradov et al. 2015). We began to study the diversity of fungi in this lake from the year 2008. Presumably, soil from the coast is more habitable for fungi than bottom sediments; therefore, we mainly focused on the investigation of the lake's shore-line, whereas fungi from the bottom sediments were described in less detail. The fungi were isolated from the peat, soil and sediment samples taken from the coast, littoral and bottom of the lake in 2008-2010. Our isolation method recovered culturable basidiomycetous, ascomycetous and zygomycetous fungi, which were identified using morphological and cultural features as well as DNA sequence data (ITS rDNA region, along with LSU rDNA). To make the present work more complete, we combined our new data with selected data from our previous studies of microfungi in the lake (Grum-Grzhimaylo et al. 2016). We characterized the composition, abundance and spatial distribution of fungal species from different parts of the lake and related these data to the ecological peculiarities of the lake, such as its freshening and a contact with the Sea.

\section{Materials and methods}

\section{Description of the Kislo-Sladkoe Lake}

The Kislo-Sladkoe Lake ["Sour-Sweet" Lake; its other name is Polupresnoe ("Brackish") Lake] is located near the Karelian coast of Kandalaksha Bay of the White Sea $2 \mathrm{~km}$ east of the Pertsov White Sea Biological Station (Online Recourse 1). The climatic and geomorphological characteristics of this area have been given earlier (Grum-Grzhimaylo et al. 2016). The Kislo-Sladkoe Lake is oval-shaped, $100 \mathrm{~m}$ long, $60 \mathrm{~m}$ wide, occupying $1.6 \mathrm{ha}$, with an average depth of $1.5 \mathrm{~m}$ and a maximum depth of $4.5 \mathrm{~m}$. The drainage area of the lake is $157.0 \mathrm{~m}^{2}$. In 2010, its elevation was $0.4 \mathrm{~m}$ above sea level (Schaporenko et al. 2005; Krasnova et al. 2014). Its basin is being formed as a result of separation of a water area between a small unnamed island covered with pines and the mainland shore of Kindo Cape (Fig. 2). In the past, the bed of the strait was bound from two sides by two submerged ridges, which rose to the surface because of the general rise of the land and formed isthmuses separating the lake area from the Great Salma Strait. One of the isthmuses is covered with grass and appears to be inundated only during seasonal snow melting when the lake is overfilled. The second isthmus consists of rolled boulders and pebble. A weak water exchange with Kandalaksha Bay takes place in the surface layer through this isthmus during high tides (once a month for 2-3 days). A weak water exchange is likely to exist through the entire northern shore of the lake. The southern shore is swampy and very weak though permanent creek flows into the sea over a steep slope of the peninsula. Underwater springs, which freshen the lake water, can also exist (Schaporenko et al. 2005). The vertical structure of the lake is characterized by seasonal and interannual variations (Vinogradov et al. 2015). Water characteristics from each of the layers in 2010 are shown in the Online Recourse 2.

Coastal vegetation of the lake is a mosaic. Different plant communities including littoral, bog and forest vegetation constantly change one after another along the shore. The circular position of the primary sea-coast vegetation is indicative for the coastal rising (Sidneva 2008; Grum-Grzhimaylo 2013; Yatzenko et al. 2017).

\section{Sampling}

The samples of soil, peat and bottom sediments were collected from several locations along the overgrown coast, littoral edge and bottom of the lake (Fig. 2; Tables 1, 2). Soil samples from the coast and littoral at the surface and $0.1 \mathrm{~m}$ depth, forest soil at the different horizons (two profile cuts), plants (living and dead parts of the moss Sphagnum spp.), and peat samples at 0.15 and $0.3 \mathrm{~m}$ depths were taken using a knife and transferred to sterile Petri dishes. The knife was cleaned with water and $96 \%$ alcohol following each extraction. The bottom sediment samples were collected every $0.5 \mathrm{~m}$ at different depths by SCUBA diving and placed in sterile tubes. All the samples were taken at one replication per season. Some locations were sampled twice (in different years). The collected samples were transported in a cold container to the laboratory and stored at $5{ }^{\circ} \mathrm{C}$ for $1-2$ days until plating.

\section{Fungal isolation, cultivation, identification and data analysis}

Dilutions were prepared from all the samples using $1 \mathrm{~g}$ in $10 \mathrm{~mL}$ of sterile distilled water, pounded in a mortar, and further diluted 100-fold. From this final dilution, $0.25 \mathrm{~mL}$ was pipetted onto two Petri plates each of six media: malt extract agar, water agar, citric-acid buffer agar, sphagnum extract agar, alkaline buffer agar and brackish water agar with the water from the lake. The media preparation and fungal cultivation were performed as described previously (Grum-Grzhimaylo et al. 2016). The identification of the fungi by morphologic and cultural characters was performed using manuals (Raper and Fennell 1965; Raper et al. 1968; Rifai 1969; von Arx 1981; Ellis 1971; Gams 1971, 2000; Barnett and Hunter 1972; Schipper 1978; Kohlmeyer and Kohlmeyer 1979; Carmichael et al. 1980; Bissett 1982, 1984; de Hoog et al. 2000; Schroers 2001; Zare and Gams 2001; Klich 2002; Samson et al. 2004; Crous et al. 2007; Domsch et al. 2007; Samson 


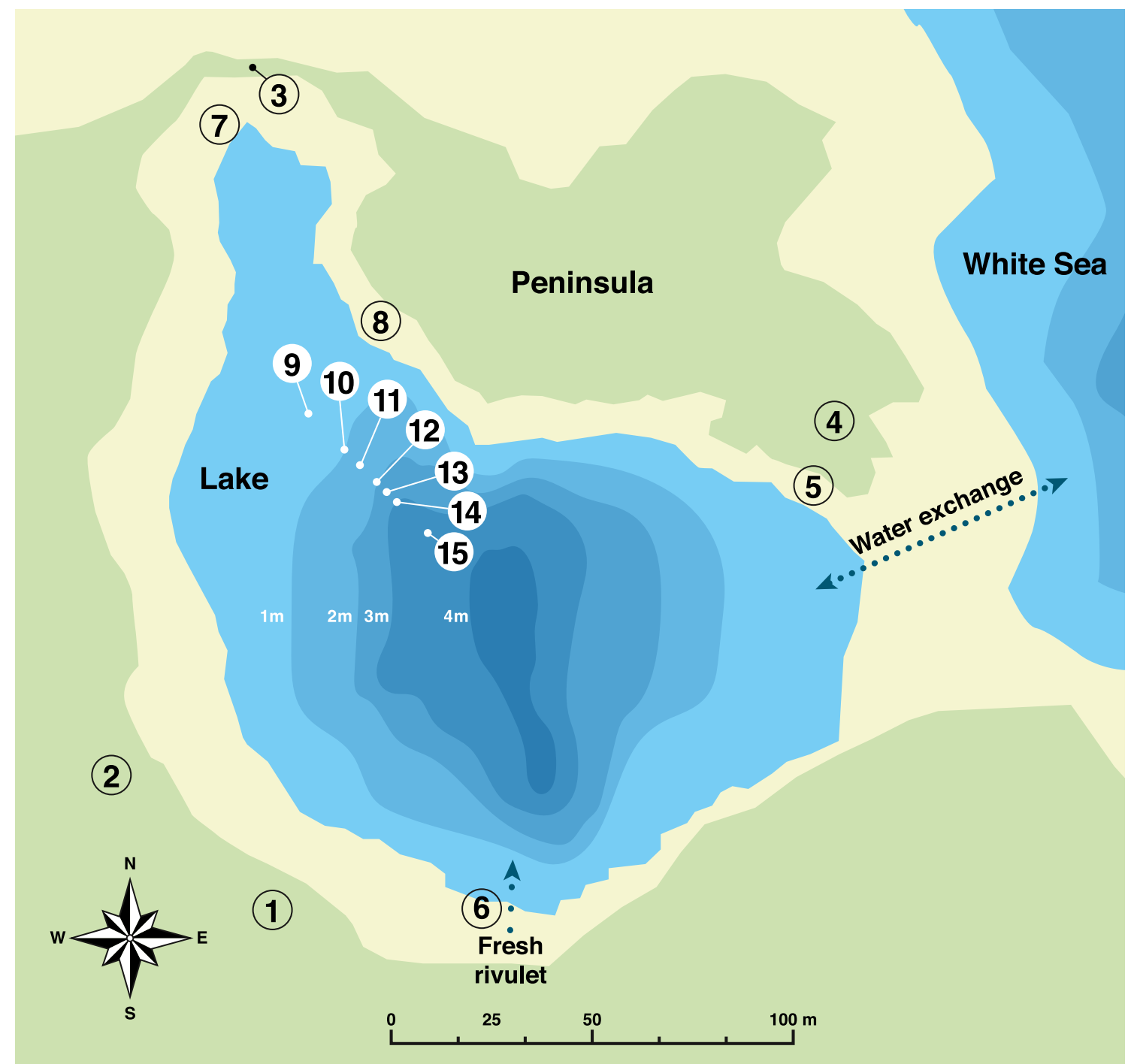

Fig. 2 Scheme of the Kislo-Sladkoe Lake, the sampling points are: 1 sphagnum peat, 2 boreal podzol, 3 muck land, 4 seashore grassed soil, $5-7$ ooze, 8 coarse sand, $9-15$ bottom sediments

and Houbraken 2011; Seifert et al. 2011). The morphologycal analysis was carried out with light microscopes (Mikmed-2, Carl Zeiss Axioskop 40 FL, Leica DM 2500). The information regarding fungal classification generally follows the Index Fungorum (http://www.indexfungorum. org) databases. The fungal strains which failed to sporulate following incubation (for 30 days) were considered sterile mycelia. A substantial part of the sterile mycelia and sporulating strains that were hard to identify by morphology were identified by DNA sequence analysis of the ITS and LSU regions of the nuclear-encoded rDNA. The same analysis was conducted for dominant fungal species in order to verify identification by morphological characters. Total genomic DNA (gDNA) was extracted from the mycelium of the 109 fungal strains using the chloroform/isopropanol method (Karakousis et al. 2006; Grum-Grzhimaylo et al.
2016). We amplified and sequenced the ITS rDNA for all strains and LSU rDNA for the most of them using common primer sets. The primer sets, thermocycling programs and sequencing procedures were performed as described previously (Grum-Grzhimaylo et al. 2016). Sequences were compared with the data from GenBank using BLAST similarity searches. Newly generated sequences were deposited in the GenBank. The GenBank Accession Numbers of 36 species from the lake are in our previous work (GrumGrzhimaylo et al. 2016), and the others given in the Online Resource 3.

Data on the total number of fungi were expressed as colony-forming units (CFU) $\mathrm{g}^{-1}$ of dry peat, as described previously (Grum-Grzhimaylo et al. 2016). The Sørensen index was used to compare fungal communities between the different parts of the lake (Zak and Willig 2004). 


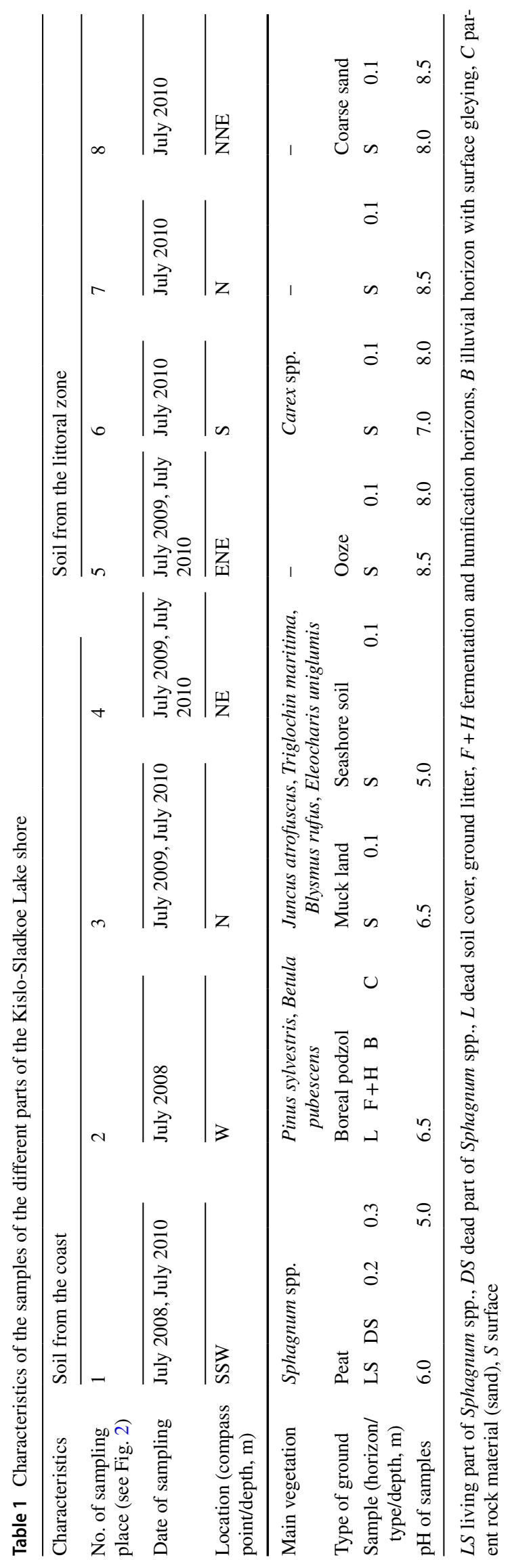


Table 2 Characteristics of the samples of the different parts of the Kislo-Sladkoe Lake bottom sediments

\begin{tabular}{llllllll}
\hline $\begin{array}{l}\text { No. of sampling place } \\
\text { (see Fig. 2) }\end{array}$ & 9 & 10 & 11 & 12 & 13 & 14 & 15 \\
\hline Date of sampling & July 2010 & & & & & \\
$\begin{array}{l}\text { Depth, m } \\
\text { Type of ground }\end{array}$ & $\begin{array}{l}0.5 \\
\text { Oozy bottom }\end{array}$ & 1.0 & 1.5 & 2.0 & 2.5 & 3.0 & 3.5 \\
$\begin{array}{l}\text { Sample (horizon) } \\
\text { pH of samples }\end{array}$ & $\begin{array}{l}\text { Surface } \\
6.0\end{array}$ & 6.0 & 5.5 & 5.0 & 6.0 & 6.0 & 5.5 \\
\hline
\end{tabular}

\section{Results}

In total, 313 fungal isolates were obtained from the 42 samples of different types of soils around the lake and its bottom sediments. These isolates belonged to 127 taxa, representing 40 genera and 28 sterile unidentified morphotypes (Table 3). Of these taxa, 111 (71.2\%) were Ascomycota, 8 (5.1\%) Basidiomycota, and 8 (5.1\%) Zygomycota. The number of viable fungal propagules ranged from $10^{2}$ to $10^{5} \mathrm{CFU}$ $\mathrm{g}^{-1}$ of the sample dry weight. Taxonomic identification of all taxa was based on morphological characters, while 40 of them (109 isolates) were identified using molecular markers (ITS and LSU rDNA), including the majority of the sterile mycelia (86 of 114 isolates), together with 13 species which were impossible to identify by morphology and a few frequent species (10 taxa).

The dominance of the fungi from the Ascomycota division was a common characteristic of the mycobiota from all parts of the lake due to abundance of the anamorphic species. The predominant genera were Penicillium (mostly Monoverticillata) and Talaromyces (Table 3).

The following genera were widely represented in all parts of the lake: Acremonium, Cladosporium, Cadophora, Trichoderma, Lecanicillium, Mucor, Umbelopsis, Aspergillus, Tolypocladium, Cordyceps (was presented by anamorphic stages from the genera Beauveria и Parengyodontium), Talaromyces and Penicillium.

In the sphagnum peat (Figs. 2 point 1, 4), the following species dominated: Acremonium spp., Cadophora luteo-olivacea, Hypocreales sp., Penicillium montanense, Metapochonia bulbillosa, Tolypocladium cylindrosporum, Cladosporium antarcticum, C. allicinum, C. cladosporioides, and C. herbarum. Cadophora luteo-olivacea, Talaromyces funiculosus and Tolypocladium inflatum were frequently found in grassed soil (Figs. 2, points 3, 4, 4); Penicillium glabrum, P. montanense, Trichoderma polysporum and Umbelopsis ramanniana in the forest soil (Figs. 2, point 2, 4). Acremonium spp., Antrodia sp., Paradendryphiella salina, Sistotrema brinkmannii, Penicillium aurantiogriseum, $P$. funiculosum, P. glabrum, P. thomii, Penicillium sp., Tolypocladium cylindrosporum, T. inflatum, Trichoderma harzianum and $T$. viride predominated in the littoral soils (Figs. 2, points 5-8, 3 ), and Cladosporium cladosporioides in the benthic ooze
(Figs. 2, points 9-15, 3). The sterile mycelium morphotypes were often isolated from all components of the lake, except for the forest and silted soils (Fig. 2, points 2, 3, 6, 7).

The greatest level of similarity in the fungal species composition was identified for the mycobiota of littoral zone and the lake benthic ooze, while the lowest level was found between the ooze and the sphagnum peat. The similarity of the fungal communities between the different parts of the lake ranged from 0.09 (between the sphagnum peat and the bottom sediments) to 0.23 (between the littoral zone and the bottom sediments) (Table 4$)$.

In the 24 samples taken from different points along the lakeshore that were not flooded during high tides (Fig. 2, points 1-4; Table 1), 88 fungal morphotypes were distinguished. The largest number of fungal taxa was found in samples of the living part of the sphagnum moss and sphagnum peat (Fig. 2, point 1) and grass-overgrown soil (Fig. 2, point 4). Penicillium montanense was identified in all layers of the sphagnum peat deposit, and all horizons of the forest and grass-overgrown soil. Penicillium glabrum and Trichoderma polysporum were also isolated from all the horizons of the forest soil (Fig. 2, point 2). Cladosporium antarcticum, C. allicinum, C. herbarum, Tolypocladium cylindrosporum and Acremonium spp. were recovered from the peat-bog layers (Fig. 2, point 1). Talaromyces funiculosus and Tolypocladium inflatum were found to be common in the grass-overgrown soil (Fig. 2, point 4), and Acremonium sp. 2 and Plectosphaerella sp. in the silted soil (Fig. 2, point 3). Cladosporium, Cordyceps (Beauveria spp., Parengyodontium album), Tolypocladium, Penicillium, Umbelopsis, Cadophora and sterile mycelium were the most widely represented fungi in the sphagnum peat (Fig. 2, point 1). In the grass overgrown soil (Fig. 2, point 4), Acremonium, Cadophora, Cordyceps and Penicillium were found with high frequency, while Penicillium was maximally represented in the forest soil (Fig. 2, point 2), andAcremonium, Fusarium and Trichoderma in the silted soil (Fig. 2, point 3 ). Two species of Oidiodendron were found only in the sphagnum peat (Fig. 2, point 1; Table 3).

The littoral zone of the lake (Fig. 2, points 5-8) is characterized by different soil properties and plant communities, which vary depending on the distance to the sea or freshwater basins. Eleven soil samples from the littoral zone 


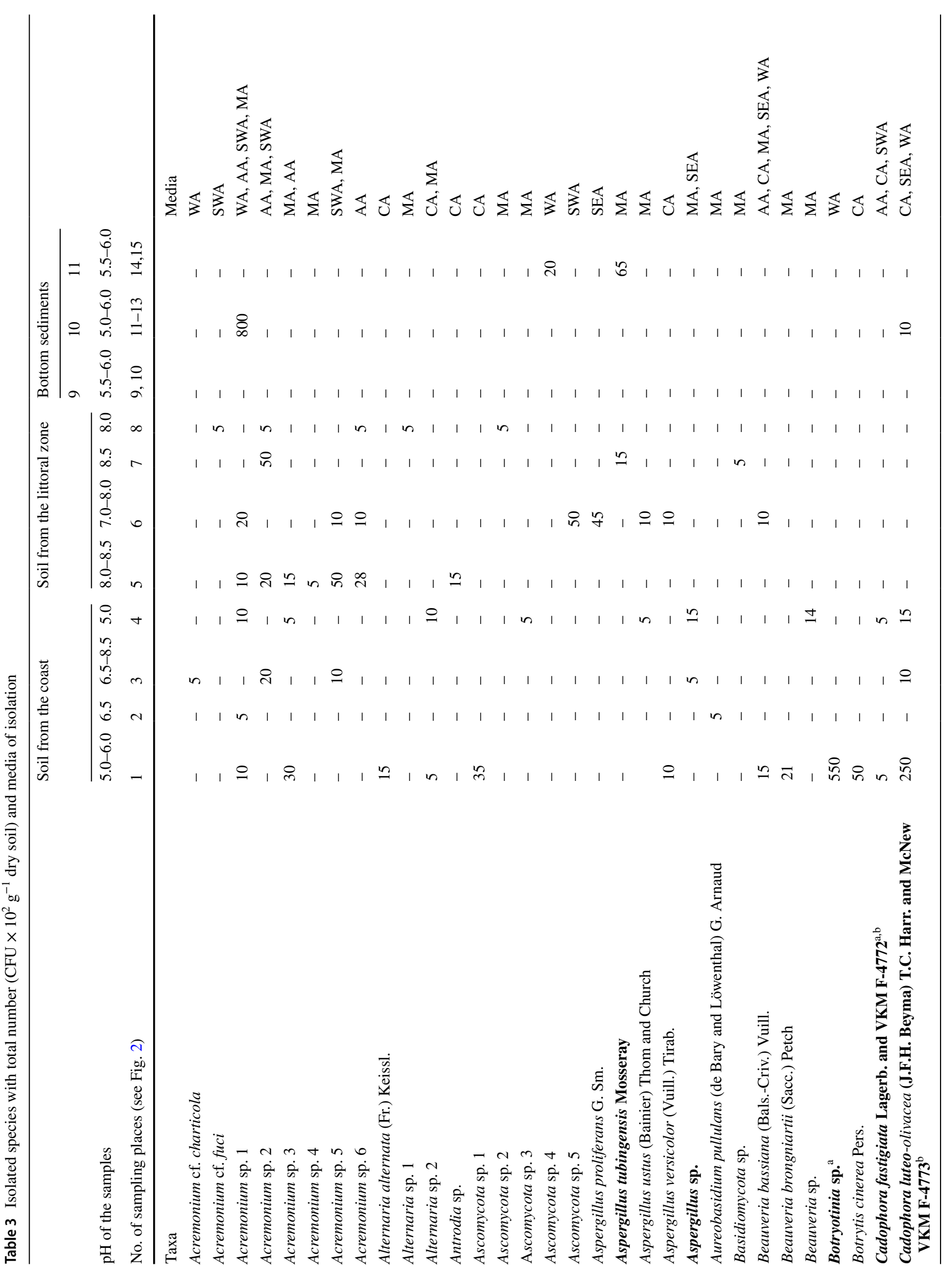




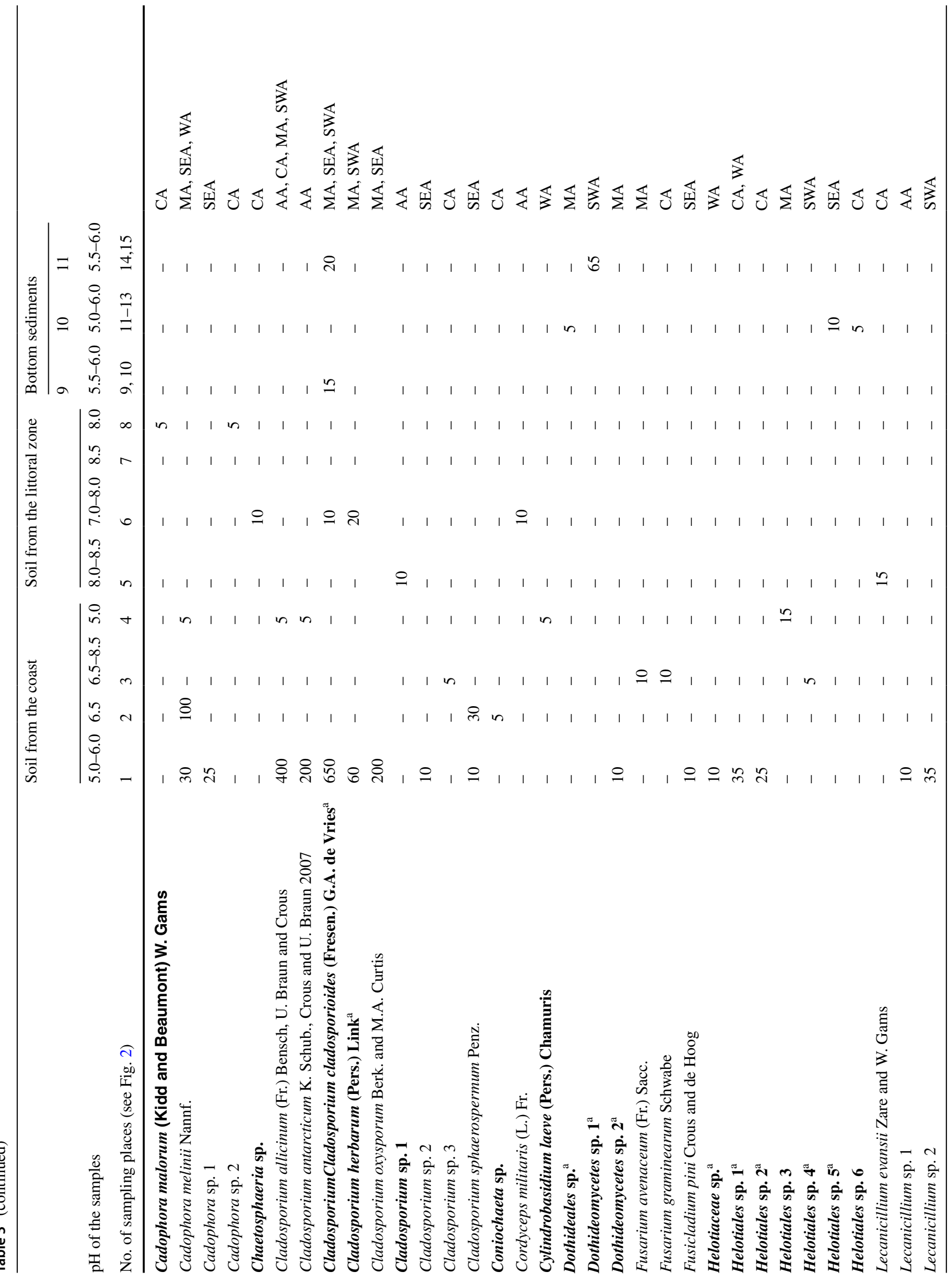




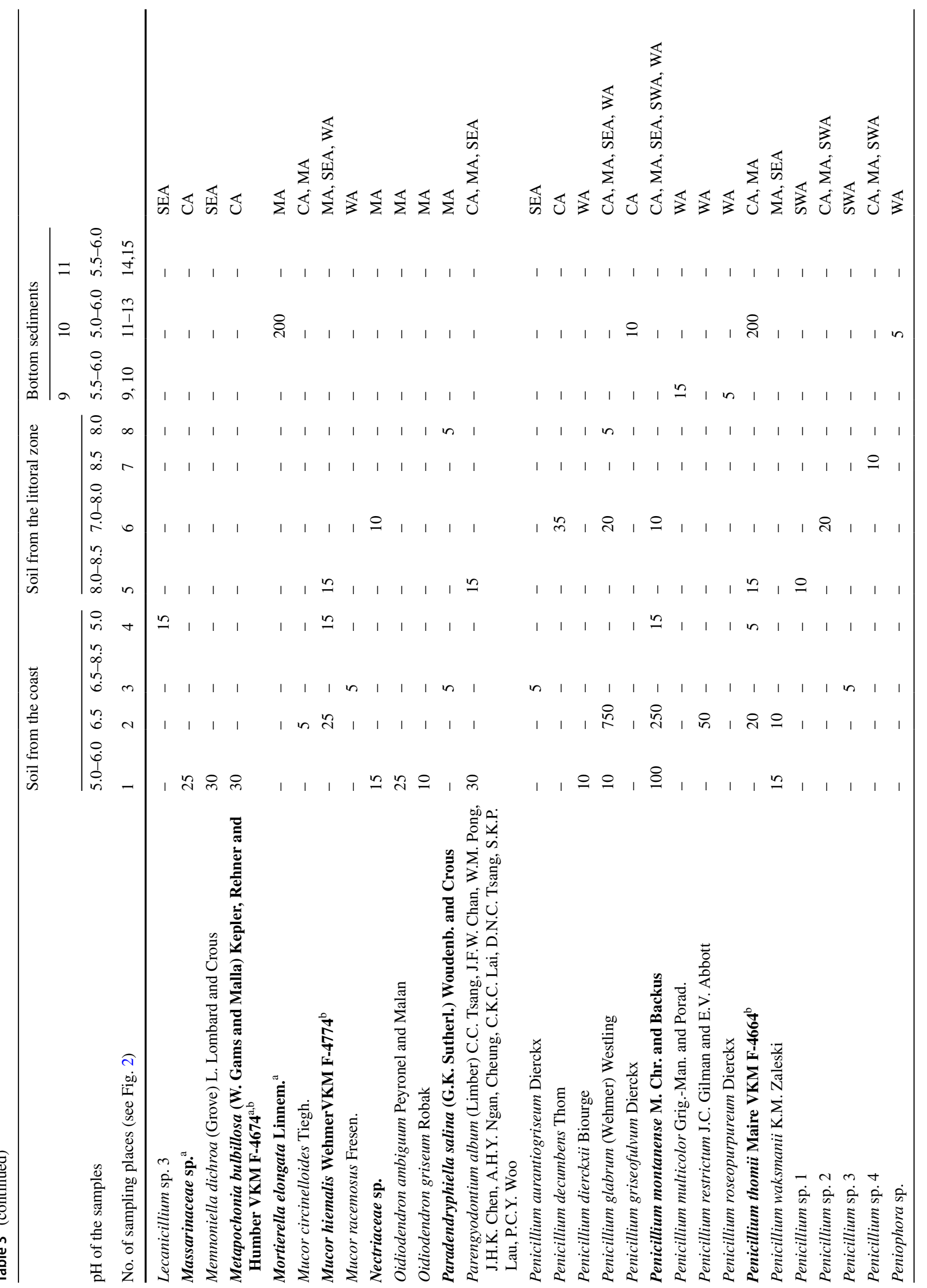




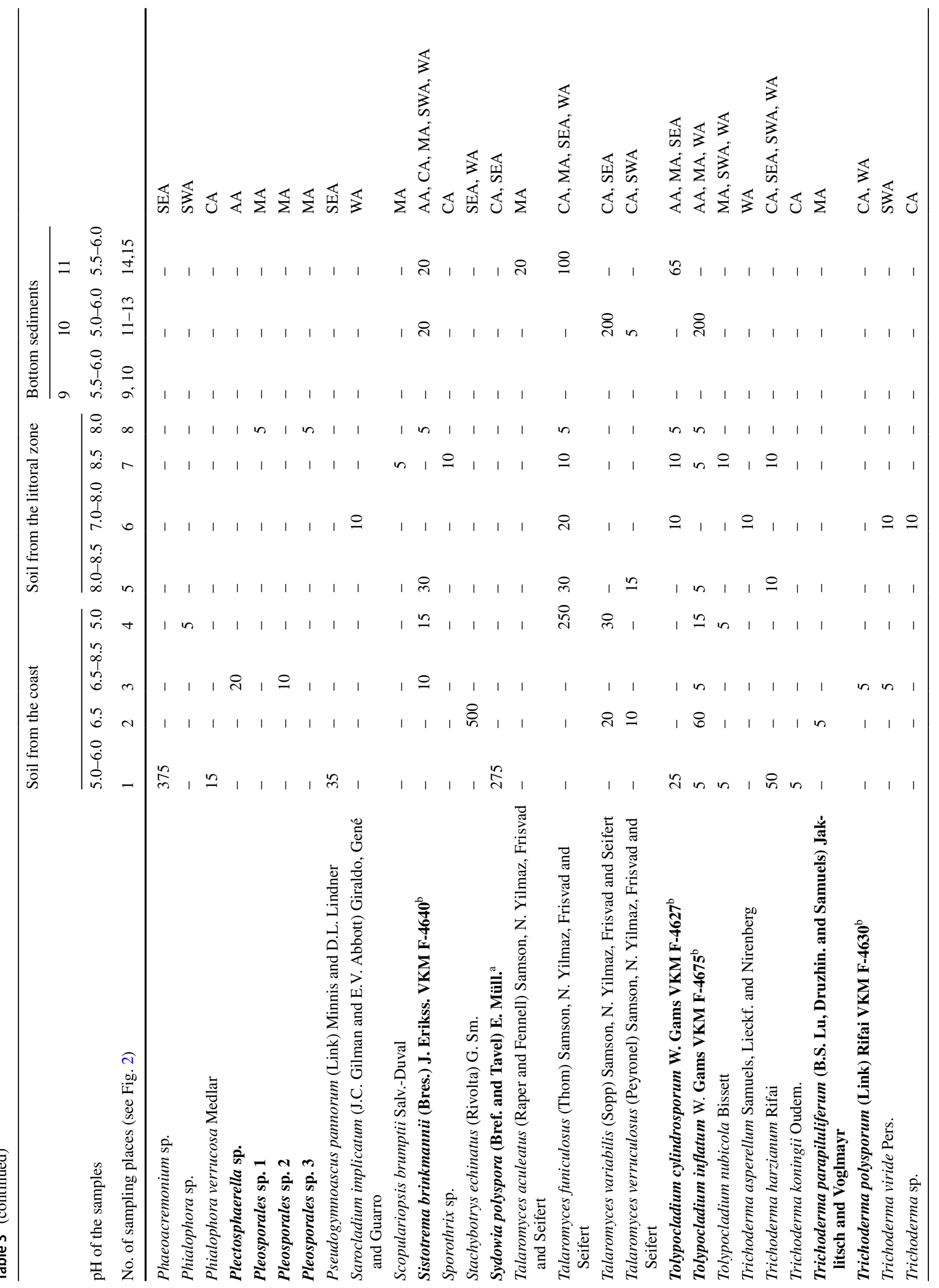


of the lake yielded 63 morphotypes of fungi. Samples that were collected from the surface yielded about 3-4 times more fungal taxa than in samples collected at a depth. The maximum number of fungal taxa (21) was observed in a sample of surface silt taken close to the river confluence area (Fig. 2, point 6). In general, the soils at the lake always contained Penicillium spp. and sterile mycelia. Genera such as Acremonium, Tolypocladium, Trichoderma, Aspergillus and Cladosporium were also widely represented (Table 3). The analysis of the spatial frequency of occurrence showed that the predominant fungi in the soil of the Kislo-Sladkoe Lake littoral were Acremonium spp., Talaromyces funiculosus, Sistotrema brinkmannii, Tolypocladium cylindrosporum, $T$. inflatum, Paradendryphiella salina, Penicillium glabrum, $P$. thomii, and Trichoderma viride (Fig. 4).

In total, 33 fungal taxa were identified in the samples collected from the lake's bottom sediment (Fig. 2, points 9-15). The number of fungi from the bottom sediment in various samples varied from 4 to 7 . The lake benthic ooze harbored Cladosporium spp., Talaromyces spp., Penicillium spp., Tolypocladium spp., and Sistotrema spp., while the remaining genera were represented by a single species, and the sterile mycelia by 10 morphotypes (Table 3 ).

\section{Discussion}

The Kislo-Sladkoe Lake is an interesting system to study, as it shares features of both fresh- and seawater environments. We hypothesized that such a transitional ecosystem would contain a unique composition of fungal biodiversity. Earlier studies on typical terrestrial peatlands in the same area showed a drastically different set of fungi (GrumGrzhimaylo and Bilanenko 2012; Bilanenko and GrumGrzhimaylo 2016; Grum-Grzhimaylo et al. 2016). Thus, our current study highlights the unusual hydrology of the lake, which in turn has resulted in the establishment of a specific fungal community. This could be explained by the distinctive physical, chemical and hydrological conditions, characteristic to the lake, which possesses a direct connection to the sea and, as a consequence, contains coastal vegetation, algoflora, microorganisms and animals different from the continental water basins that serve as a source of food for the fungi. At the level of higher rank taxa, such as divisions and classes, the fungal communities in the peatlands of the Kindo peninsula are characterized by a similar taxonomy. As the distance from the sea increases, the composition of the dominant species of fungi in the peat and swamp ooze of the peatlands changes. We found similar species of fungi in a specific component (e.g., peat or ooze) between the peatlands, rather than in the peat and ooze of a single peatland. The sphagnum peat of the lake coast (Fig. 2, point 1) is thin in comparison with other studied peat bogs in the area (Grum-Grzhimaylo 


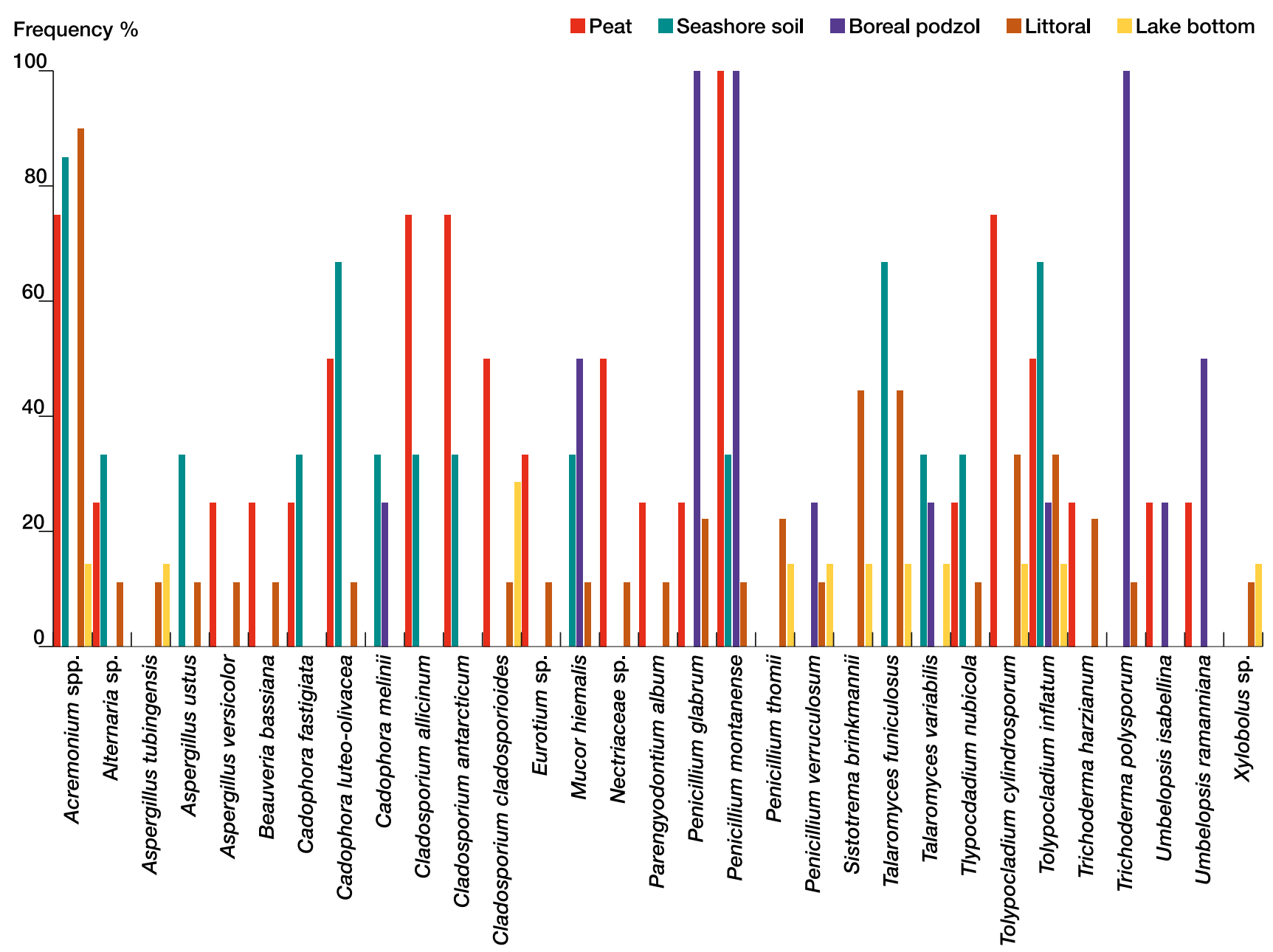

Fig. 3 The spatial frequency of the most abundant fungal species in the Kislo-Sladkoe Lake

Table 4 Similarity of fungal communities of the different parts of the Kislo-Sladkoe Lake (Sørensen index)

\begin{tabular}{|c|c|c|c|c|}
\hline & $\begin{array}{l}\text { Grassland } \\
\text { soil }\end{array}$ & Forest soil & Littoral zone & Lake bottom \\
\hline $\begin{array}{l}\text { Sphagnum } \\
\text { peat }\end{array}$ & 0.20 & 0.18 & 0.21 & 0.09 \\
\hline $\begin{array}{l}\text { Grassland } \\
\text { soil }\end{array}$ & - & 0.21 & 0.20 & 0.15 \\
\hline Forest soil & - & - & 0.11 & 0.12 \\
\hline Littoral zone & - & - & - & 0.23 \\
\hline
\end{tabular}

et al. 2016). From the lake, despite the unfavorable conditions of the sphagnum peat (recalcitrant cell walls of sphagnum moss, abundant phenolic compounds, anoxia), we isolated a large diversity of fungi, including Acremonium spp., Alternaria spp., Aspergillus versicolor, Beauveria spp., Botryotinia sp., Botrytis cinerea, Cadophora spp., Cladosporium spp., Oidiodendron spp., Lecanicillium spp., Penicillium spp., Talaromyces funiculosus, Tolypocladium

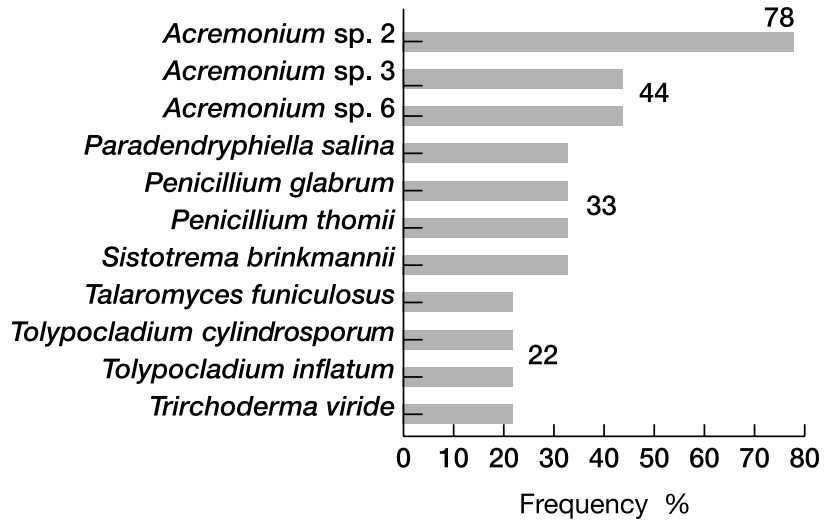

Fig. 4 The spatial frequency of fungal species (with the spatial frequency $\geq 22 \%$ ) in the littoral of the Kislo-Sladkoe Lake

spp., Trichoderma spp., Umbelopsis spp., sterile mycelia, some of which (Cadophora sp. 1, Cadophora luteo-olivacea, Cladosporium sp. 2, Cladosporium sphaerospermum, 
Fusicladium pini, Helotiales sp. 5, Lecanicillimm sp. 3, Penicillium aurantiogriseum, Phaeoacremonium sp, Pseudogymnoascus pannorum, and Stachybotrys dichroa) appeared only on the media which were based on the sphagnum extract (Table 3). Contrary to typical terrestrial peat, the sphagnum peat of the lake harbored a substantially larger fraction of fungi which are indicative of marine habitats, such as Acremonium, Cadophora, Cladosporium, and Tolypocladium (Online Resource 4). The fungal composition in the peat bogs of the terrestrial lakes in the area (Verkhneye, Krugloye and Yershovskoye Lakes), which have already separated from the sea, is similar, despite the different age and altitude above sea level (Grum-Grzhimaylo et al. 2016).

The benthic ooze (Fig. 2, points 9-15) is a more dynamic system due to differences in the organic matter inflow, exposure to external physical, chemical and hydrological conditions, and to the presence of marine sediments therein. Therefore, the fungal composition of the ooze was unique and differed between different lakes, except for sterile mycelia, the proportion of which was much higher compared to the peat. The ooze of both the terrestrial lakes and brackish lakes contained typical marine fungi of Acremonium which, by BLAST similarity search, are close to $A$. fuci, A. potronii and A. strictum (Jones et al. 2009). Thus, the presence of typical marine-borne fungi in the ooze of all the studied lakes reflects the process of their separation from the sea.

To make a direct comparison with the marine habitats, we compared the fungal composition of the lake with the fungal community in the bottom sediments of the Velikaya Salma Strait (part of the White Sea near the lake). Bubnova et al. (2014) detected three obligate marine species in the sediments (Acremonium fuci, Paradendryphiella arenaria and $P$. salina), all the rest were classified as land-origin species. The fungal composition was represented mainly by the cosmopolitan species (Penicillium spp.) and typical soil species for this region (Pseudogymnoascus pannorum, Penicillium spp., Tolypocladium spp., and Trichoderma spp.). The distinctive feature of the fungal composition in the bottom sediments was a high abundance and rich diversity of Acremonium spp., which are known to often occupy marineborne habitats (Bubnova et al. 2014). These fungi were also found in our samples taken from the littoral zone of the lake, especially at sites where sea water flows in. BLAST search results showed that all of them were close to the obligate and facultative marine species of Acremonium.

Many of the dominating and frequent species distinguished from different components of the lake appeared to be typical representatives of nearby habitats (Acremonium spp., Penicillium spp., Tolypocladium spp., and Trichoderma spp.).

Of note, the littoral samples, which are the closest to the sea (Fig. 2, points 5,7), were enriched with the fungi typically found in marine habitats (Paradendryphiella salina,
Acremonium cf. fuci, and Cadophora spp.). Conversely, the peat samples from the shore, which are desalinated and covered with vegetation (Fig. 2, points 1,2,4), contained fungal species commonly associated with peat bogs (Oidiodendron spp., Penicillium thomii, P. montanense). Penicillium montanense was recovered from all the samples of the coastal area (forest soil, sphagnum peat, meadow soil and the place of the freshwater brook confluence), but was not found in samples taken at places connected to the sea or in benthic ooze sediments. It can be assumed that $\mathrm{pH}$ values inhibit the spread of this species. Penicillium montanense is often noted in acidic habitats, such as decomposing bogs and fens, needle litter, and the rhizosphere of coniferous (Thormann et al. 2004; Osono et al. 2006), while sea water has an alkaline reaction.

Selective media makes it possible to recover slowly growing oligotrophic and acid-tolerant species that are able to thrive under unfavorable conditions, such as low $\mathrm{pH}$ and the presence of recalcitrant compounds of sphagnum moss. The highest number of species was isolated on malt extract agar and citric acid buffer agar media. However, the use of alkaline and neutral media allowed us to identify the alkalitolerant and neutrophilic species (Acremonium spp., Plectosphaerella sp.) characteristic of many parts of the lake. The results of using the different media are shown in Online Resource 5. DNA-based identification was most useful with basidiomycetous fungi, though also with ascomycetous species of the Helotiales and Pleosporales. BLAST search results showed that many of our pleosporalean isolates from the lake were close to known marine species, such as Bissothecium circinans and Loratospora aestuarii (Schoch et al. 2009). Similarly, fungi from the Helotiales have often been found in marine habitats (Wang et al. 2006). In our studies of the fungi in the Kindo peninsula pealtland lakes, the major part of the Helotiales were found in the lake (Table 5). Presumably, this is related to the fact that conditions in this lake are more similar to the sea conditions in comparison with the other lakes of the Kindo peninsula. The most common basidiomycete in the lake was Sistotrema brinkmannii, which is widely distributed in deciduous and coniferous forests, and known as a late-stage wood destructor. In the current study, this species was found in the swamp peat along the peninsula and from most of the samples taken from different parts of the lake. The presence of Sistotrema brinkmannii both in the littoral soil and benthic sediments of the water basins is intriguing, and its exact role in these wood-free habitats warrants further research.

Our investigations revealed that the fungal communities in the Kindo peninsula peat and lakes depend on their origin. Since the lake is similar in its properties to the other lakes that we studied in the WSBS area (depth less than $5 \mathrm{~m}$ and presence of a freshwater flow), it could be assumed that the lake would develop in the same way-from eutrophic 

distribution in the Kislo-

Yershovskoye, Krugloye and

Verkhneye lakes
Table 5 Helotiales taxa

Sladkoe Lake, and the

\begin{tabular}{lc}
\hline Lake & $\begin{array}{l}\text { Num- } \\
\text { ber of } \\
\text { taxa }\end{array}$ \\
\hline Kislo-Sladkoe & 15 \\
Ershovskoye & 8 \\
Krugloye & 2 \\
Verkchneye & 9 \\
\hline
\end{tabular}

to oligotrophic, through the mesotrophic and upper aapatype swamp stages (Olunina 2008). Hence, in the process of their waterlogging, as well as in other swamps, there will be a respective change in plant communities, the organic composition of sediments, and, consequently, in the fungal content. The presence of both typical marine species and species characteristic for freshened water basins, soil and peat, indicates the lake's transitional stage from the sea to a groundwater basin, resulting in a combination of abiotic factors. In future research, it would be of interest to study the functional role and adaptation trajectories of fungi in such environments.

Acknowledgements We thank Alexander Tzetlin (director of the WSBS) for the opportunity to carry out this research, Elena Vortsepneva and Alexander Semenov for their help with sample collection, Bertha Koopmanschap, Marijke Slakhorst and Alex Grum-Grzhimaylo for technical assistance, and Denis Landin for image processing. The work was supported by the Laboratory of Genetics at Wageningen University (molecular research; OG, AD), the Russian Foundation for Basic Research (\# 15-29-02553; the field investigation and identification of the fungi; EB, OG), the Russian Science Foundation (\# 14-5000029; the cultivation and collection of the fungi; OG) and the Erasmus Mundus IAMONET-RU. Light microscopy study was conducted using equipment of the Center of microscopy WSBS MSU.

\section{Compliance with ethical standards}

Conflict of interest The authors declare that they have no conflict of interest.

Open Access This article is distributed under the terms of the Creative Commons Attribution 4.0 International License (http://creativeco mmons.org/licenses/by/4.0/), which permits unrestricted use, distribution, and reproduction in any medium, provided you give appropriate credit to the original author(s) and the source, provide a link to the Creative Commons license, and indicate if changes were made.

\section{References}

Barnet HL, Hunter BB (1972) Illustrated genera of imperfect fungi, 3rd edn. Burgess, Minneapolis

Bilanenko EN, Grum-Grzhimaylo OA (2016) A comparative analysis of the cultured micromycetes in oligotrophic peatlands of natural biosphere reservations located in the northern and central parts of Russia. Nat Conserv Res Zapovednaya nauka 1:90-95
Bisset J (1982) Notes on Tolypocladium and related genera. Can J Bot 61:1311-1329

Bissett J (1984) A revision on the genus Trichoderma. Can J Bot 62:924-931

Bubnova EN (2017) Diversity of the microscopic fungi in the littoral sands of the White Sea. Moscow Univ Biol Sci Bull 72:121-127. https://doi.org/10.3103/S0096392517030026

Bubnova EN, Grum-Grzhimaylo OA, Konovalova OP, Marfenina OE (2014) Fifty years of mycological studies at the White Sea biological station of Moscow State University: challenges, results, and outlook. Moscow Univ Biol Sci Bull 69:23-39. https://doi. org/10.3103/S0096392514010039

Carmichael JW, Kendrick WB, Conners IL, Sigler L (1980) Genera of hyphomycetes. University of Alberta Press, Canada

Crous PW, Braun U, Schubert K, Groenewald JZ (2007) The genus Cladosporium and similar dematiaceous hyphomycetes. Stud Mycol 58:1-253

Damare S, Raghukumar C (2008) Fungi and Macroaggregation in Deep-Sea Sediments. Microb Ecol 56:168-177. https://doi. org/10.1007/s00248-007-9334-y

Damare S, Raghukumar C, Raghukumar S (2006) Fungi in deep-sea sediments of the Central Indian Basin. Deep-Sea Res 53:14-27. https://doi.org/10.1016/j.dsr.2005.09.005

de Hoog GS, Guarro J, Gene J, Figueras MJ (2000) Atlas of clinical fungi. Centraalbur voor Schimmelcult, Utrecht

Dickman MD (1978) A possible varving mechanism for meromictic lakes. Quat Res 11:113-124.

Domsch KH, Gams W, Anderson T-H (2007) Compendium of soil fungi. IHWg, Eching

Ellis MB (1971) Dematiaceous hyphomycetes. Commonwealth Mycological Institute, Kew

Furbino LE, Pellizzari FM, Neto PC, Rosa CA, Rosa LH (2017) Isolation of fungi associated with macroalgae from maritime Antarctica and their production of agarolytic and carrageenolytic activities. Polar Biol. https://doi.org/10.1007/s0030 0-017-2213-1

Gams W (1971) Cephalosporium-artige Schimmelpilze (Hyphomycetes). Gustav Fischer, Stuttgart

Gams W (2000) Phialophora and some similar morphologically little differentiated anamorphs of divergent ascomycetes. Stud Mycol 45:187-199

Gibson JAE, Vincent WF, Van Hove P (2002) Geochemistry of icecovered, meromictic Lake A in the Canadian High Arctic. Aquat Geochem 8:97-119. https://doi.org/10.1023/A:1021317010302

Grum-Grzhimaylo OA (2013) Micromycetes of bogs at the Kandalaksha Bay of the White Sea. Dissertation, Lomonosov Moscow State University (in Russian)

Grum-Grzhimaylo OA, Bilanenko EN (2012) The micromycete complexes of bogs at the Kandalaksha Bay of the White Sea. Mikol I Fitopatol 46:297-305 (in Russian)

Grum-Grzhimaylo OA, Debets AJM, Bilanenko EN (2016) The diversity of microfungi in peatlands originated from the White Sea. Mycologia 108:233-254. https://doi.org/10.3852/14-346

Gulati RD, Zadereev ES, Degermendzhi AG (2017) Ecology of Meromictic Lakes. Springer, Berlin

Hakala A (2004) Meromixis as a part of lake evolution—observations and a revised classification of true meromictic lakes in Finland. Boreal Environ Res 9:37-53

Hammer $\varnothing$, Harper DAT, Ryan PD (2001) PAST: paleontological statistics software package for education and data analysis. Palaeontol Electron 4:1-9

Jones EBG, Sakayaroj J, Suetrong S, Somrithipol S, Pang KL (2009) Classification of marine ascomycota, anamorphic taxa and basidiomycota. Fungal Divers 35:1-187

Karakousis A, Tan L, Ellis D, Alexiou H, Wormald PJ (2006) An assessment of the efficiency of fungal DNA extraction methods 
for maximizing the detection of medically important fungi using PCR. J Microbiol Methods 65:38-48. https://doi.org/10.1016/j. mimet.2005.06.008

Klich MA (2002) Identification of common Aspergillus species. Centraalbur voor Schimmelcult, Utrecht

Kohlmeyer J, Kohlmeyer E (1979) Marine mycology-the higher fungi. Academic, New York

Krasnova ED, Pantyulin AN, Belevich TA et al (2013) Multidisciplinary studies of the separating lakes at different stage of isolation from the White Sea performed in March 2012. Oceanology 53:639-642. https://doi.org/10.1134/S0001437013050068

Krasnova ED, Pantyulin AN, Matorin DN, Todorenko DA, Belevich TA, Milyutina IA, Voronov DA (2014) Cryptomonad alga Rhodomonas sp. (Cryptophyta, Pyrenomonadaceae) bloom in the redox zone of the basins separating from the White Sea. Microbiology 83:270-277. https://doi.org/10.1134/S00262617140301 02

Krasnova E, Voronov D, Frolova N, Pantyulin A, Samsonov T (2015) Salt lakes separated from the White Sea. EARSeL eProc 14:822. https://doi.org/10.12760/02-2015-1-02

Lepère C, Domaizon I, Hugoni M, Vellet A, Debroas D (2016) Diversity and dynamics of active small microbial eukaryotes in the anoxic zone of a freshwater meromictic lake (Pavin, France). Front Microbiol 7:130. https://doi.org/10.3389/fmicb .2016 .00130

Ludlam SD (1996) The comparative limnology of high arctic, coastal, meromictic lakes. J Paleolimnol 16:111-131

Lutz H, Kaulfuß U (2006) A dynamic model for the meromictic lake Eckfeld Maar (Middle Eocene, Germany). Z Dt Ges Geowiss 157:433-450. https://doi.org/10.1127/1860-1804/2006/0157-0433

Malyshko E, Nesmeyanova E, Ilchenko S et al (2015) Quantitative benthic distribution in Kislo-Sladkoe Lake. EARSeL eProc 14:1-7. https://doi.org/10.12760/02-2015-1-01

McAndrews JH, Turton CL (2010) Fungal spores record Iroquoian and Canadian agriculture in 2nd millennium a.d. sediment of Crawford Lake, Ontario, Canada. Veg Hist Archaeobot 19:495-501

Oikonomou A, Filker S, Breiner H-W, Stoeck T (2015) Protistan diversity in a permanently stratified meromictic lake (Lake Alatsee, SW Germany). Environ Microbiol 17:2144-2157. https://doi. org/10.1111/1462-2920.12666

Olunina ES (2008) Peatlands of the Kindo Peninsula and Veliky Island (Kandalaksha Bay of the White Sea): flora, current vegetation, peat deposit and history of formation. Mat nauch konf, posv 70-letiu BBS, Moscow, pp 207-212 (in Russian)

Osono T, Hirose D, Fujimaki R (2006) Fungal colonization as affected by litter depth and decomposition stage of needle litter. Soil Biol Biochem 38:2743-2752. https://doi.org/10.1016/j.soilb io. 2006.04 .028

Pantiulin AN, Krasnonva ED (2011) Separating basins of the White Sea: new field for interdisciplinary research in Geology of Seas and Oceans. Proc 19th Int Conf (School) Mar Geol 3:241-245 (in Russian)

Pouliot J, Galand PE, Lovejoy C, Vincent WF (2009) Vertical structure of archaeal communities and the distribution of ammonia monooxygenase a gene variants in two meromictic High Arctic lakes. Environ Microbiol 11:687-699. https://doi.org/10.111 1/j.1462-2920.2008.01846.x

Rämä T, Hassett BT, Bubnova E (2017) Arctic marine fungi: from filaments and flagella to operation taxonomic units and beyond. Bot Mar 60:433-452. https://doi.org/10.1515/bot-2016-0104

Raper KB, Fennell DI (1965) The genus Aspergillus. Williams and Wilkins, Baltimore

Raper KB, Thom C, Fennell DI (1968) A manual of the Penicillia. Hafner, London
Rifai MA (1969) A revision on the genus Trichoderma. Mycol Pap 116:1-56

Samson RA, Houbraken J (2011) Phylogenetic and taxonomic studies on the genera Penicillium and Talaromyces. Stud Mycol 70:1-183

Samson RA, Hoekstra ES, Frisvad JC (2004) Introduction to food- and airborne fungi. Centraalbur voor Schimmelcult, Utrecht

Schaporenko SI, Koreneva GA, Pantyulin AN, Pertsova NM (2005) Characteristics of the ecosystems of water bodies separating from Kandalaksha Bay of the White Sea. Water Resour 32:469-483

Schipper MA (1978) On certain species of Mucor with a key to all accepted species: 2. On the genera Rhizomucor and Parasitella. Stud Mycol 17:1-71

Schoch CL, Sung GH, López-Giráldez F, Townsend JP, Miadlikowska J, Hofstetter V et al. (2009) The Ascomycota tree of life: a phylum-wide phylogeny clarifies the origin and evolution of fundamental reproductive and ecological traits. Syst Biol 58:224-239

Schroers H-J (2001) A monograph of Bionectria (Ascomycota, Hypocreales, Bionectriaceae) and its Clonostachys anamorphs. Stud Mycol 46:1-216

Seifert K, Morgan-Jones G, Gams W, Kendrick B (2011) The genera of Hyphomycetes. CBS KNAW Biodiversity Center, Utrecht

Sidneva EH (2008) Vegetation changes in connection with coastal rising (WSBS locality, Veliky Island). Mat nauch konf, posv 70-letiu BBS, Moscow, pp 203-207 (in Russian)

Strelkov P, Shunatova N, Fokin M, Usov N, Fedyuk M, Malavenda S, Lubina O, Poloskin A, Korsun S (2014) Marine Lake Mogilnoe (Kildin Island, the Barents Sea): 100 years of solitude. Polar Biol 37:297-310. https://doi.org/10.1007/s00300-013-1431-4

Takishitaa K, Tsuchiyaa M, Kawatoa M, Ogurib K, Kitazatob H, Maruyama T (2007) Genetic diversity of microbial eukaryotes in anoxic sediment of the saline Meromictic Lake Namako-ike (Japan): on the detection of anaerobic or anoxic-tolerant lineages of eukaryotes. Protist 158:51-64. https://doi.org/10.1016/j.proti s.2006.07.003

Thormann MN, Currah RS, Bayley SE (2004) Patterns of distribution of microfungi in decomposing bog and fen plants. Can J Bot 82:710-720. https://doi.org/10.1139/b04-025

Van Hove P, Belzile C, Gibson JAE, Vincent WF (2006) Coupled landscape-lake evolution in High Arctic Canada. Can J Earth Sci 43:533-546. https://doi.org/10.1139/e06-003

Vinogradov D, Varlamov S, Volovich N, Kuznetsov V, Grigoryeva A, Mardashova M, Krasnova E (2015) Hydrological and spectrophotometry research on Kislo-Sladkoe Lake. EARSeL eProc 14:55-62. https://doi.org/10.12760/02-2015-1-08

von Arx JA (1981) The genera of fungi sporulating in pure culture, 3rd edn. Cramer, Vaduz

Wang Z, Binder M, Schoch CL, Johnston PR, Spatafora JW, Hibbett DS (2006) Evolution of helotialen fungi (Leotiomycetes, Pezizomycotina): a nuclear rDNA phylogeny. Mol Phylogenet Evol 41:295-312. https://doi.org/10.1016/j.ympev.2006.05.031

Yatzenko OV, Grum-Grzhimaylo OA, Yatsenko IO (2017) Characteristic of vegetation of the Kislo-Sladkoe Lake-detaching lake from the sea at the White Sea coast. In: Exploration, sustainable use and protection of natural resources of the White Sea. ZIN, SaintPetersburg, pp 263-266 (in Russian)

Zak J, Willig M (2004) Fungal biodiversity patterns. Biodiversity of fungi: inventory and monitoring methods. Elsevier, Burlington, pp 59-72

Zare R, Gams W (2001) A revision of Verticillium section Prostrata. IV. The genera Lecanicillium and Simplicillium gen. nov. Nova Hedwigia 73:1-5 